\title{
Comparative analysis of the criminal offence of the trafficking of human organs in the recently- formed countries of the Balkans
}

\begin{abstract}
The trafficking of human organs is a complex crime. In this respect, law enforcement institutions are confronted with wide-ranging problems in following the right path, beginning with the identification of criminal activity, the identification of the trafficking victim, the full investigation of the case and the taking of measures to bring the case to court so that the criminal has to face deserved punishment. The purpose of this article is to make a comparative analysis of the criminal offence of the trafficking of human organs in those states formed out of the former Yugoslavia, including the types and weights of criminal sanctions that are foreseen in the criminal codes in these states. It is apparent that some states in the region need to make changes to the provisions of their Criminal Codes in order to incriminate some forms of this offence, including as regards potential victims including children, women, elderly people, disabled people and others with limited capacities. Further work also needs to be done concerning potential perpetrators including corporate entities, medical professionals and criminal groups.
\end{abstract}

Keywords: organ trafficking, cells and tissues, criminal sanctions, criminal organisations, transnational issues, developing countries

Introduction

The trafficking of human organs is one of the main components of organised crime; today, this is no longer myth or legend but a tangible reality as it has become a global, regional and national phenomenon of sizable and wide-sweeping proportions. International, regional and national criminal organisations, separately, but also in alliance with one another, are the main problem and challenge for all institutions, law enforcement organisations and structures, international police agencies and state and social structures as a whole, since they constitute a major threat to the democratic system and society as well as to human fundamental rights and freedoms.

Criminal groups are tracking developments in technology on a step-by-step basis. Using technology, they are carefully able to monitor economic, political and legislative developments around the world in order to spread criminal activity to countries that have encountered developmental problems; most frequently targeted are precisely those states which are under-developed.

Due to profits being high and the risks of a successful prosecution of offenders being low - and when it is known that most of the countries in the region are not economically developed, that they do not have political or legal stability and that 
most are not members of the EU - it is clear that, in such circumstances, there is sufficient space for individuals or organised groups to take action in these countries to commit criminal offences related to trafficking, especially in the trafficking of human organs as a special form of the criminal offence of human trafficking. It is more than necessary for the states of the region to take appropriate action in order to include all possible actors in the commission of this criminal offence and to incorporate the different types of sanction that, in addition to prison sentences, are envisaged by legislation and criminal codes. Consequently, states and regions in south-east Europe need to harmonise their criminal policy approach concerning trafficking in human organs with those of EU member states and countries. This would include the incorporation of additional punishments and financial sanctions.

\section{Reflections on and comparisons of the basic form of the criminal offence of trafficking in human organs}

The taking, and buying and selling, of trafficked human organs may be presented both as an aspect, and as an act of committing, a complex, transnational offence. This is the case as long as the following elements are present:

1. the international legal concept of international criminal law is formed

2. the acquisition or trade of bodies or body parts as a concept is countered with transnational work in which states undertake obligations to engage legally with the issue at national level, such as drafting a national normative framework and harmonising regulations with other states; as well as seeking international co-operation in terms of prevention and punishment. ${ }^{1}$

By signing the Council of Europe Convention against Trafficking in Human Organs, states are obliged to approve, within their national legislature or criminal codes, particular legal provisions in respect of criminal liability for the unlawful removal of human organs (Article 4). Action concerning the removal of human organs is characterised as illegal where there is not 'free, informed and specific' consent in the donation of organs or, otherwise, where there is a financial gain accruing from removal of the organs of a living or deceased donor (Article 4, paragraph 1, item a, $b, c)$. The Convention further deals with the:

- use of organs illegally removed for implantation or other purposes (Article 5)

- the implantation of organs outside the domestic transplantation system or in contravention of the fundamental principles of the law regarding domestic transplantation (Article 6)

- the unlawful solicitation, recruitment and the offer and request of unfair advantages (Article 7)

- the preparation, preservation, storage, transportation, transfer, receipt, import and export of illicitly removed human organs (Article 8)

1 Boister, N (2003) 'Transnational Criminal Law?' European Journal of International Law 14(5): 953-976, available at: http://www.ejil.org/pdfs/14/5/453.pdf. 
- corporate liability (Article 11$)^{2}$ regarding the liability both of those corporate entities which have identity as a legal person and individuals acting individually or as part of a body of a legal person.

However, we need to note at the outset that most of the countries in the region have, in their own legislative systems, or criminal codes, incorporated as a basic form of trafficking in human organs the actions foreseen in the European Convention on Action against Trafficking in Human Beings and not as envisaged by the European Convention against Human Organ Trafficking.

The basic form of the criminal offence of trafficking in human organs is contained in the same legal provision as the criminal offence of trafficking human beings is foreseen in countries of the region as follows:

- the Republic of Macedonia in Article 418a Trafficking in Human Beings ${ }^{3}$

- in the Criminal Code of the Republic of Serbia in Article 388 Trafficking in Human Beings 4

- in the Criminal Code of the Republic of Slovenia in Article 113 Trafficking in Human Beings 5

- in the Criminal Code of Bosnia and Herzegovina in Article 186 International Trafficking in Human Beings. ${ }^{6}$

The use of particular terminology in the descriptions both of performance and of purpose should be understood in the sense that such terms are used in the relevant criminal offences in criminal codes; and that - crucially - in order to understand some of them, it is necessary to keep in mind the international protocols that give meaning to such expressions as well as the other international conventions in similar fields. $^{7}$

In the Criminal Code of the Republic of Kosovo, Article 265 envisages within the same provision the criminal offences of the illegal transplantation and trafficking of human bodies and cells. ${ }^{8}$ When we compare the provisions of the criminal codes of those states that have determined, as a specific offence, the trafficking of human

2 Directive 2004/23/EC of the European Parliament and of the Council (31 March 2004) on Setting standards of quality and safety for the donation, procurement, testing, processing, preservation, storage and distribution of human tissues and cells, available at: http://eur-lex.e uropa.eu/Lex-UriServ/LexUriServ.do?uri=OJ:L:2004:102:0048:0058:en:PDF.

3 Krivični zakonik Rep. Makedonije [Criminal Code of Macedonia] (Sl. Vesnik na RM br. 80/99, 4/2002, 43/2003, 19/2004, 81/2005, 60/2006, 73/2006, 87/2007, 7/2008, 139/2008, 114/2009, $51 / 11,135 / 11,185 / 11,42 / 12,166 / 12,55 / 13,82 / 13,14 / 14,27 / 14,28 / 14,41 / 14,115 / 14$, 132/14, 160/14, 199/14, 196/15, 226/15 i 97/2017).

4 Krivčni zakonik Srbije [Criminal Code of Serbia] (Sl. glasnik RS br. 85/2005, 88/2005 - ispr., 107/2005 - ispr., 72/2009, 111/2009, 121/2012, 104/2013, 108/2014 i 94/2016).

5 Kaznenski zakonik Rep. Slovenije [Criminal Code of Slovenia] (Uradni list RS št. 50/2012).

6 Krivični Zakon Bosne i Hercegovine [Criminal Code of Bosnia and Herzegovina] (Službeni glasnik BiH br. br. 3/03, 32/03, 37/03, 54/04, 61/04, 30/05, 53/06, 55/06, 32/07, 8/10, 47/14, 22/15, 40/15).

7 Stojanović, Z (2016) Komentar Krivičnog zakonika Beograd, at p. 1071.

8 Kodi Penal $i$ Republikës së Kosovës [Criminal Code of Kosovo] (Nr. 04/L-82 i dates 20 prill 2012). 
organs, the Criminal Code of Kosovo contains significant legal gaps in comparison, for example, with the criminal codes of Croatia and Montenegro because it encompasses within the same provision the offences of the illegal transplanting and trafficking of human organs and cells.

However, among recently-established Balkan states, there are some which have made specific provisions in the trafficking of human organs. In Croatia's criminal code, Article 107 foresees the criminal offence of trafficking of human organs and embryos, a provision which is directly related to the provisions of Article 106, which refers to the trafficking of human organs. ${ }^{9}$

In contrast, the Criminal Code of Montenegro, sets out separately the legal provisions related to the organ trafficking, as follows:

- Article 293a deals with the unlawful taking of human organs and body parts

- Article 293b concerns the preservation, transport, import and export of human organs or body parts taken as a result of the commission of a criminal offence

- Article 295a concerns the trafficking of body parts

- Article 295b concerns the trafficking of the body parts of a deceased person where permission to do so was expressly denied while the person was alive.

Most relevantly, we should record that these are separate provisions from the criminal offences of trafficking people and trafficking children as a form of trafficking people. ${ }^{10}$

Thus, in Croatia - and, even more so, in Montenegro - out of all the countries involved in this research study, the basic provisions of the criminal codes relating to organ trafficking do indeed comply with the Council of Europe Convention against Trafficking in Human Organs.

The trafficking of human organs is a particularly complex crime in which law enforcement agencies face wide-ranging problems. The Medicus case in Kosovo shows how complex is human organ trafficking and what it is essential to describe in detail in specific provisions of the criminal code if this trade is to be stopped. EULEX Special Prosecutor Jonathan Ratel, in his final speech, highlighted that, in the infamous case of the Medicus Clinic:

78 witnesses testified, 103 court hearings converted to 525 hours were held, 21 testimonies were received through video link, 5 expert testimonies, 29 files with thousands of documents and 30 requests for international legal assistance are filed - all these fall within this case.

9 Kazneni zakon Rep. Hrvatske [Criminal Code of Croatia] (N.N. 125/11, 144/12, 56/15, 61/15, 101/17).

10 Krivični zakonik Crne Gore [Criminal Code of Montenegro] (Službeni list CG br. 40/2008, 25/2010, 32/2011, 64/2011 - drugi zakon, 40/2013, 56/2013, 14/2015, 42/2015, 58/2015 drugi zakon i 44/2017). 
Each country in the region needs to bear in mind that the World Health Organization has invited member states to:

Take measures to protect the poorest and most vulnerable groups from transplant tourism and the sale of organs and tissues, paying attention to the most problematic wide international purchase of tissues and human organs. ${ }^{11}$

Penal sanctions are indeed foreseen for the criminal offence of human organ trafficking in recently-formed Balkan states which are the subject of this study.

Modern criminal policy, though increasingly oriented towards preventive social action and rehabilitation, has not given up on the function of penal sanctions, penalties and having special bodies responsible for implementing and executing these laws and penalties. Within the penal policy elements of each system, special attention is paid to the penalties imposed on the perpetrators of criminal offences during criminal proceedings. $^{12}$

We need to observe carefully that trafficking in human organs, alongside trafficking in drugs, people, weapons, diamonds, gold and oil, represents an illegal trade on an industrial scale which is worth billions of dollars across the globe. ${ }^{13}$

The United States Institute for Integration and Finance, in its 2011 report, estimated that human organ trafficking can generate unlawful benefits of between $\$ 600 \mathrm{~m}$ and $\$ 1.2 \mathrm{bn}$ annually. ${ }^{14}$ In its 2017 report, it estimated that illegal organ trafficking generated between $\$ 840 \mathrm{~m}$ and $\$ 1.7 \mathrm{bn}$ per year. This consideration applies to the illegal sale of five commonly traded organs: kidneys; livers; hearts; lungs; and pancreas. There is a significant difference in the amount that donors pay and the amount the recipient receives, which - furthermore - often reflects differences between developed and developing countries: thus, for example, the kidney 'price' in developed countries is $\$ 20000$, while in developing countries the price is $\$ 3000-$ the difference a whopping 500 per cent. ${ }^{15}$

Consequently, it is clear that organised criminal groups have significantly increased their incomes between 2011 and 2017, meaning that they have been able to continue and extend throughout the world their criminal activities related to organ trafficking.

11 WHO (2010) Revised Guiding Principles on Human Cell, Tissue and Organ Transplantation Resolution WHA63.22.

12 Latifi, V (2008) Politika Kriminale Prishtinë, p. 162.

13 Beširević, V, N. Codreanu, E. Demény, G. T. Florea, J. Sándor (2012) Improving the effectiveness of the organ trade prohibition in Europe - Recommendations Chişinău: EULOD; available at: http://hottproject.com/userfiles/Publicaties/ENGIMPROVINGTHEEFFECTIVENESSOFTHEORGANTRADEPROHIBITIONINEUROPE.pdf, p. 7.

14 Haken, J (2011) Transnational crime in the Developing World Washington DC: Global Financial Integrity, p. 22.

15 May, Channing (2017) Transnational Crime and the Developing World Washington DC: Global Financial Integrity, available at: https://www.gfintegrity.org/report/transnational-cri me-and-the-developing-world/, pp. 29, 31. 
In order to encourage the countries of the region to embed strong and comprehensive provisions regarding the trafficking of human organs, we have compared for this article the provisions of country criminal codes related to the type and level of criminal sanctions as foreseen by each of the codes. We have divided our recently-formed states into three groups dependent on how they regulate the issue of trafficking human organs.

\section{Group 1}

Here, we have those states that foresee the same criminal offences for human organ trafficking as for the criminal offence of trafficking people (Bosnia and Herzegovina, Macedonia, Slovenia and Serbia).

Among the criminal codes of all these states, it is evident that there are some legal vacuums in that some serious elements within the trafficking process are not incriminated as criminal offences.

For example: in the Criminal Code of Bosnia and Herzegovina, it is not foreseen as a serious offence if, during the commission of the criminal offence in harvesting organs, there is serious injury or a serious deterioration in the health of the person concerned, or even their death. Additionally, those entities which constitute legal persona, and which are potential perpetrators of criminal offences, are not incriminated as offenders.

Neither in the Criminal Code of Macedonia is there a criminal offence where there is serious injury, serious loss of health or the death of a person as a result of attempts at organ harvesting.

In Slovenia's Criminal Code it is not incriminated as an offence where this is committed by a medical professional, or when it is committed by an entity with a legal persona, or when a serious injury or death of the person is caused due to the offence.

Additionally, the Criminal Code of Serbia incriminates neither medical professionals nor entities with legal persona as potential perpetrators of criminal offences.

These legal vacuums create a revolution in legal practice and put judges and prosecutors in the respective states in unenviable situations.

Comparing the levels of sanction in these 'first group' states, it is clear that, in Bosnia and Herzegovina, there is a higher sentence envisaged for the basic offence, as well as all other forms, compared to other states. In terms of severity of sanction, it is clear that also Macedonia, compared to Slovenia and Serbia, has a more rigorous criminal policy. In contrast in Slovenia, as a member of the European Union, there are much lower penalties than in all other countries taken for comparison in the first group (as a reminder, these have been grouped as a result of them seeing within the same legal provision the criminal offence of trafficking people and the criminal offense of trafficking human organs, cells and tissues.

\section{Group 2}

Kosovo foresees criminal offences in the illegal transplantation and trafficking of human organs and cells in Article 265 of its Criminal Code. Paragraph 5 of this Arti- 
cle concerns the trafficking of human organs for which punishment is foreseen of a term of imprisonment of between two and twelve years. Furthermore, the Criminal Code of Kosovo, Articles 171 and 172, which deal with the criminal offence of human trafficking, is clearly related to the criminal offence of illegal transplantation and organ and cell trafficking under Article 265.

If we compare with the states in the first group, it is evident that, in the Criminal Code of Kosovo, the level of punishment is higher both in the basic form and in the more serious ones. It is also worth mentioning that, in the case of Kosovo, financial penalties are also foreseen alongside prison terms, which was not the practice for 'first group' states.

However, the provisions of the Criminal Code of Kosovo do contain legal vacuums in that organisations with legal identities are not incriminated as potential perpetrators of criminal offences.

\section{Group 3}

Here, we have states which foresee special provisions for the criminal offences of trafficking in human bodies and human embryos: in this group are Croatia and Montenegro.

Considering that trafficking in human organs and human embryos is related in the Croatian Criminal Code to the criminal offense of trafficking people, we can see that this is unsustainable if they are treated separately because of the direct relationship which the Code draws between legal provisions in these areas.

The forms of the provisions relating to trafficking in human body parts and human embryos contained within the Croatian Criminal Code gives the right direction on which to focus in the future regarding organ trafficking. This is the case even though in these provisions we encounter legal vacuums regarding the criminal offence of trafficking in human beings, including:

- non-incrimination of entities with legal persona as possible perpetrators of criminal offences

- non-incrimination of medical professionals when they are aware that the organ for which a transplant or a certain legal experiment is being performed is a result of the criminal offence of the trafficking of body parts

- provisions regarding organ trafficking not creating special protection even for those people who are most vulnerable to being part of the organ trafficking trade, i.e. women, older people, disabled people, and so on.

However, in comparison with states from the first and second groups, the Group 3 states do incriminate certain actions that are not incriminated by those elsewhere. For example, criminal codes in this group do incriminate the trafficking of dead bodies and the trafficking of cells and tissues, including egg and sperm cells, embryos and foetuses.

It is also made clear in codes within this group that the actions of people who remove organs may correspond to criminal offences in conjunction with the criminal offence of bodily harm or grievous bodily harm. Given that such criminal offences 
may be motivated by greed, a financial penalty may be imposed where they have been committed. ${ }^{16}$

As we saw earlier, the Criminal Code of Montenegro envisages separate provisions for the criminal offence of organ trafficking as well as for trafficking people and trafficking children as a form of trafficking people. These provisions of the Criminal Code of Montenegro clearly regulate organ trafficking in a more advanced way than other countries studied as a part of this work.

Even so, there are again legal vacuums in the Criminal Code of Montenegro. For example, it is clear that these provisions do not incorporate incrimination as a criminal offence of:

- legal entities as potential perpetrators

- medical professionals when they are aware that the organ for which transplantation is being performed or a certain legal experiment conducted is as a result of the offence of trafficking in human body parts

- the harvesting of body parts of those who are most vulnerable to being part of the organ trafficking trade (women, the elderly, disabled people, people with certain physical and psychological weaknesses, and so on).

It is worth pointing out that the Criminal Code of Montenegro incriminates as the perpetrator of a criminal offence anyone who, in the mass media, issues proclamations regarding the purchase and sale of organs, cells, tissues, embryos, foetuses or the bodies of the deceased. This is an appropriate precautionary measure to deal with all those who, by abusing the internet and social networks in particular, are able to attract people who need body parts as recipients on the one hand and, on the other, those who, due to difficult economic conditions or extreme poverty, are forced to sell organs as donors for the purpose of obtaining a certain sum of money.

People who make such donations often appear as rescuers, and people love both the donors and the recipients of organ transfers; but it is important to make a distinction between altruism and those who are working for their own financial and partisan interests and for which the sale of body parts is a simple commodity transaction.

\section{Sanctions}

Considering the criminal penalties that are foreseen in all the criminal codes of the countries within the region, it may be noticed that imprisonment is chiefly foreseen as the main punishment. The exceptions are the Republic of Macedonia, where the main penalty is a fine for entities with legal persona; while in the Republic of Kosovo the imposition of a prison sentence is a possibility alongside that of a fine for medical professionals and criminal organisations, or those acting on behalf of criminal organisations.

We may recall that none of the legal provisions sanctioning the perpetrator of the criminal offence of human trafficking, in addition to the punishment of imprisonment as the main penalty, provide for simultaneous fines or additional financial penalties on the perpetrators of such offenses, as is practicable in some other European coun- 
tries. For example, Article 601 of the Criminal Code of Italy states that anyone who unlawfully trades, sells, buys or in any way and for whatever reason assists the removal of organs or body parts from a living person, shall be punished by imprisonment from between three and twelve years as well as a fine of $€ 50$ 000-300 000. If this offence is carried out by healthcare staff (a doctor), he or she faces a 'perpetual prohibition from professional practice'. ${ }^{17}$ In the 2010 Criminal Code of Spain, Article 156 provides that, in accordance with the provisions of Article 31, the responsible person of a legal entity is liable for the criminal offences and should pay a punishment of three to five times more than the annual profit. ${ }^{18}$

\section{Conclusion}

According to the European Council Convention against Trafficking in Human Organs, every signatory party is obliged to undertake appropriate legal and other measures within their domestic legal systems which determine criminal offences for the trafficking of human organs.

Differences in the treatment of criminal offences of the trafficking of human beings for the purposes of exploitation in prostitution or other forms of sexual exploitation, trafficking in human beings for the purpose of exploitation for forced labour or services and trafficking in human beings for the purpose of slavery or similar practices, on the one hand, and trafficking in human organs and human tissue and cells, on the other, will help legal professionals in the correct assessment of the criminal offence which has been conducted and facilitate the imposition of adequate punishment. What is important in either case is the presence of a relevant legal definition in line with the relevant European Council convention, as well as a consideration of the main legal elements of the offence that has been committed (in terms of actions, tools, and purpose).

The states of the region must correctly define the concrete provisions in this regard in specific sections of their criminal codes, under which trafficking in human organs, cells and tissue will clearly be considered a criminal offence alongside the incrimination of all the perpetrators involved in the crime:

- ordinary persons under the law

- entities with legal personality

- medical professionals aware that the organ for which transplantation or some legal experiment is being carried out is the result of trafficking in body parts

- people acting on behalf of criminal organisations and organisers of such groups

- people who make announcements in relation to the sale and purchase of organs, parts of organs and blood.

Criminal codes also need to give greater legal support to marginalised groups who are more likely to be potential victims of these sorts of criminal offence such as: children; women; pregnant women; the elderly; disabled people; people with limited capacities; and so on.

17 http://www.quotidianosanita.it/allegati/allegato4671710.pdf.

$18 \mathrm{http} / /$ endorganpillaging.org/2010-spanish-criminal-code-amended-to-combat-transplant-to urism-and-organ-trafficking. 
Trafficking in human organs violates human dignity and the right of life, and poses a serious threat to public health. Punitive policies against this phenomenon, which is spreading with great dynamism as a result of the extraordinary gains and the very low risk of the successful prosecution of the perpetrators of this criminal offence, should be more aggressive than now when compared to the trafficking of human beings. Furthermore, states in the region of south-east Europe also need to introduce criminal sanctions and punishments on the basis of financial and additional penalties for this very complex criminal offence, on the basis of which perpetrators may be charged and effectively punished.

\section{References}

Beširević, V, N. Codreanu, E. Demény, G. T. Florea, J. Sándor (2012) Improving the effectiveness of the organ trade prohibition in Europe - Recommendations Chișinău: EULOD; available at: http://hottproject.com/userfiles/Publicaties/ENG IMPROVINGTHEEFFECTIVENESSOFTHEORGANTRADEPROHIBITIONINEUROPE.pdf.

Boister, N (2003) 'Transnational Criminal Law?' European Journal of International Law 14(5): 953-976, available at: http://www.ejil.org/pdfs/14/5/453.pdf.

Haken, J (2011) Transnational crime in the Developing World Washington DC: Global Financial Integrity.

Latifi, V (2008) Politika Kriminale Prishtinë.

May, Channing (2017) Transnational Crime and the Developing World Washington DC: Global Financial Integrity, available at: https://www.gfintegrity.org/report/tr ansnational-crime-and-the-developing-world/.

Stojanović, Z (2016) Komentar Krivičnog zakonika Beograd.

Turković, K et al. (2013) Komenat kaznenog zakona, Zagreb.

Council of Europe Treaty Series - No. 216 Council of Europe Convention against Trafficking in Human Organs Santiago de Compostela, 25 March 2015, available at: https://rm.coe.int/CoERMPublicCommonSearchServices/DisplayDCTMContent?documentId=09000016806dca3a.

Directive 2004/23/EC of the European Parliament and of the Council (31 March 2004) on Setting standards of quality and safety for the donation, procurement, testing, processing, preservation, storage and distribution of human tissues and cells, available at: http://eur-lex.europa.eu/Lex-UriServ/LexUriServ.do?uri=OJ:L :2004:102:0048:0058:en:PDF.

WHO (2010) Revised Guiding Principles on Human Cell, Tissue and Organ Transplantation Resolution WHA63.22. http://endorganpillaging.org/2010-spanish-cri minal-code-amended-to-combat-transplant-tourism-and-organ-trafficking.

http://www.quotidianosanita.it/allegati/allegato4671710.pdf. 
Kazneni zakon Rep. Hrvatske [Criminal Code of Croatia] (N.N. 125/11, 144/12, 56/15, 61/15, 101/17).

Kaznenski zakonik Rep. Slovenije [Criminal Code of Slovenia] (Uradni list RS št. 50/2012).

Kodi Penal i Republikës së Kosovës [Criminal Code of Kosovo] (Nr. 04/L-82 i dates 20 prill 2012).

Krivčni zakonik Srbije [Criminal Code of Serbia] (Sl. glasnik RS br. 85/2005, 88/2005 - ispr., 107/2005 - ispr., 72/2009, 111/2009, 121/2012, 104/2013, 108/2014 i 94/2016).

Krivični Zakon Bosne i Hercegovine [Criminal Code of Bosnia and Herzegovina] (Službeni glasnik BiH br. br. 3/03, 32/03, 37/03, 54/04, 61/04, 30/05, 53/06, 55/06, 32/07, 8/10, 47/14, 22/15, 40/15).

Krivični zakonik Crne Gore [Criminal Code of Montenegro] (Službeni list CG br. 40/2008, 25/2010, 32/2011, 64/2011 - drugi zakon, 40/2013, 56/2013, 14/2015, 42/2015, 58/2015 - drugi zakon i 44/2017).

Krivični zakonik Rep. Makedonije [Criminal Code of Macedonia] (Sl. Vesnik na RM br. 80/99, 4/2002, 43/2003, 19/2004, 81/2005, 60/2006, 73/2006, 87/2007, $7 / 2008,139 / 2008,114 / 2009,51 / 11,135 / 11,185 / 11,42 / 12,166 / 12,55 / 13,82 / 13$, $14 / 14,27 / 14,28 / 14,41 / 14,115 / 14,132 / 14,160 / 14,199 / 14,196 / 15,226 / 15$ i 97/2017). 
